\title{
Activation of Metabotropic Glutamate Receptors Inhibits High-Voltage-Gated Calcium Channel Currents of Chicken Nucleus Magnocellularis Neurons
}

\author{
Yong Lu and Edwin W Rubel \\ Virginia Merrill Bloedel Hearing Research Center and Department of Otolaryngology-Head and Neck Surgery, \\ University of Washington, Seattle, Washington
}

Submitted 30 June 2004; accepted in final form 13 September 2004

Lu, Yong and Edwin W Rubel. Activation of metabotropic glutamate receptors inhibits high-voltage-gated calcium channel currents of chicken nucleus magnocellularis neurons. J Neurophysiol 93: 1418-1428, 2005. First published September 15, 2004; doi:10.1152/ jn.00659.2004. Using whole cell patch-clamp recordings, we pharmacologically characterized the voltage-gated $\mathrm{Ca}^{2+}$ channel (VGCC) currents of chicken nucleus magnocellularis (NM) neurons using barium as the charge carrier. NM neurons possessed both low- and high-voltage-activated $\mathrm{Ca}^{2+}$ channel currents (HVA $I_{\mathrm{Ba}^{2+}}$ ). The $\mathrm{N}$ type channel blocker ( $\omega$-conotoxin-GVIA) inhibited more than half of the total HVA $I_{\mathrm{Ba}^{2+}}$, whereas blockers of L- and P/Q-type channels each inhibited a small fraction of the current. Metabotropic glutamate receptor (mGluR)-mediated modulation of the HVA $I_{\mathrm{Ba}^{2+}}$ was examined by bath application of glutamate $(100 \mu \mathrm{M})$, which inhibited the HVA $I_{\mathrm{Ba}^{2+}}$ by an average of $16 \%$. The inhibitory effect was dose dependent and was partially blocked by $\omega$-conotoxin-GVIA, indicating that mGluRs modulate $\mathrm{N}$ and other type HVA $I_{\mathrm{Ba}^{2+}}$. The nonspecific mGluR agonist, (1S,3R)-1-aminocyclopentane-1,3-dicarbosylic acid (1S,3R-ACPD), mimicked the inhibitory effect of glutamate on HVA $I_{\mathrm{Ba}^{2+}}$. Group I-III mGluR agonists showed inhibition of the HVA current with the most potent being the group III agonist $\mathrm{L}(+)$-2-amino-4-phosphonobutyric acid. 1S,3R-ACPD $(200 \mu \mathrm{M})$ had no effect on $\mathrm{K}^{+}$or $\mathrm{Na}^{+}$currents. The firing properties of NM neurons were also not altered by $1 \mathrm{~S}, 3 \mathrm{R}-\mathrm{ACPD}$. We propose that the inhibition of VGCC currents by mGluRs limits depolarization-induced $\mathrm{Ca}^{2+}$ entry into these highly active NM neurons and regulates their $\mathrm{Ca}^{2+}$ homeostasis.

\section{N T R O D U C T I O N}

Neurons vary widely their activity patterns. Primary and secondary neurons in the auditory and vestibular systems are characterized by unusually high rates of sustained activity modulated by brief bursts of even higher spike rates to signal changes in environmental events (Born et al. 1991; Koppl 1997; Rubel and Parks 1975; Rubsamen et al. 1995; Stopp and Whitfield 1961; Sullivan and Konishi 1984; Warchol and Dallos 1990). Some motor neurons share these characteristics. Other neurons appear to have relatively low rates of action potential generation. This diversity correlates with great diversity in intracellular homeostatic and signaling mechanisms, particularly those involving $\mathrm{Ca}^{2+}$ homeostasis (Lips and Keller 1999; Vanselow and Keller 2000).

Nucleus magnocellularis (NM) neurons, the secondary afferent neurons in the avian central auditory pathways, are homologous to the bushy cells of the mammalian cochlear

Address for reprint requests and other correspondence: E. W Rubel, Virginia Merrill Bloedel Hearing Research Center and Department of OtolaryngologyHead and Neck Surgery, University of Washington, Box 357923, Seattle, WA 98195 (E-mail: rubel@u.washington.edu). nucleus. NM neurons receive an excitatory glutamatergic input from the auditory nerve and inhibitory GABAergic inputs primarily from the superior olivary nucleus (reviewed in Rubel and Fritzsch 2002; Rubel et al. 2004). NM neurons are unusually active, showing unstimulated firing rates between 50 and $100 \mathrm{~Hz}$ and rates of $250 \mathrm{~Hz}$ or more in response to acoustic stimulation. Ionotropic glutamate receptors (iGluRs) in NM are specialized for fast and temporally precise firing properties, whereas metabotropic glutamate receptors (mGluRs) appear critical for $\mathrm{Ca}^{2+}$ homeostasis (Zirpel and Rubel 1996; Zirpel et al. 1995, 1998).

$\mathrm{Ca}^{2+}$ homeostasis is critically important for cellular survival, and very active neurons appear to have mechanisms for maintaining $\mathrm{Ca}^{2+}$ homeostasis that are different or more abundant than found in other neuron types (Lips and Keller 1999; Vanselow and Keller 2000; Yu et al. 2001; Zirpel et al. 2000). Elimination of the excitatory input to NM in young chicks results in death of $\sim 30 \%$ of NM neurons and atrophy of remaining neurons (reviewed in Rubel and Fritzsch 2002). One of the early deafferentation-induced changes in NM neurons is a threefold increase in $\left[\mathrm{Ca}^{2+}\right]_{\mathrm{i}}$ (Zirpel and Rubel 1996; Zirpel et al. 1995). Orthodromic stimulation of NM neurons or mGluR stimulation prevents the deprivation-induced rise in $\left[\mathrm{Ca}^{2+}\right]_{\mathrm{i}}$ and prevents early metabolic degenerative changes (reviewed in Rubel and Fritzsch 2002). This unique role of mGluRs appears to allow NM neurons to avoid excitotoxicity under normal conditions, while processing very high rates of information flow.

Modulation of $\mathrm{Ca}^{2+}$ influx via voltage-gated $\mathrm{Ca}^{2+}$ channels (VGCCs) by mGluRs is one of the processes described in NM neurons that is hypothesized to play a role in the normal $\left[\mathrm{Ca}^{2+}\right]_{\mathrm{i}}$ regulation. Using $\mathrm{Ca}^{2+}$ imaging techniques, Lachica et al. (1995) showed that activation of mGluRs inhibits KClinduced $\mathrm{Ca}^{2+}$ influx presumably through VGCCs in NM neurons. However, mGluR-mediated modulation of VGCC currents in NM neurons has not been investigated nor do we understand which group(s) mGluRs mediate the modulation and whether other voltage-gated conductances and firing properties of NM neurons are affected by mGluRs.

In the present series of studies, we use whole cell recording techniques to examine the role of mGluR-mediated signaling pathways in $\mathrm{Ca}^{2+}$ regulation by NM neurons. Electrophysiological studies indicate that NM neurons possess both lowvoltage-activated (LVA) and high-voltage-activated (HVA) $\mathrm{Ca}^{2+}$ channel currents $\left(I_{\mathrm{Ba}^{2+}}\right)$ and N-type channels are the

\footnotetext{
The costs of publication of this article were defrayed in part by the payment of page charges. The article must therefore be hereby marked "advertisement" in accordance with 18 U.S.C. Section 1734 solely to indicate this fact.
} 
dominant HVA VGCCs; activation of mGluRs by glutamate or 1S,3R-ACPD inhibits HVA $I_{\mathrm{Ba}^{2+}}$; the modulation seems involving groups I-III mGluRs; and voltage-gated $\mathrm{Na}^{+}$channel currents $\left(I_{\mathrm{Na}^{+}}\right)$, voltage-gated $\mathrm{K}^{+}$channel currents $\left(I_{\mathrm{K}^{+}}\right)$, and firing properties of NM neurons are not altered by mGluR activation. We propose that activation of mGluRs mediates a net reduction of $\mathrm{Ca}^{2+}$ influx through VGCCs without affecting firing properties of NM neurons, and this mGluR-mediated inhibition of VGCC currents may be one mechanism whereby $\mathrm{NM}$ neurons are protected from $\mathrm{Ca}^{2+}$ overload-induced excitotoxicity. An abstract of this work has appeared (Lu and Rubel 2002).

\section{METHODS}

\section{Slice preparation}

White Leghorn chicken (Gallus domesticus) embryos (E17-E20) were used. After rapid decapitation, a thick coronal block containing the entire brain stem was dissected free into artificial cerebrospinal fluid (ACSF). The components of ACSF were (in $\mathrm{mM}$ ) $130 \mathrm{NaCl}, 3$ $\mathrm{KCl}, 1.25 \mathrm{NaH}_{2} \mathrm{PO}_{4}, 26 \mathrm{NaHCO}_{3}, 1 \mathrm{MgCl}_{2}, 10$ glucose, and $2 \mathrm{CaCl}_{2}$. The $\mathrm{pH}$ value of aerated $\left(95 \% \mathrm{O}_{2}-5 \% \mathrm{CO}_{2}\right)$ ACSF was maintained at 7.4 and osmolality was $280-310 \mathrm{mosM} / \mathrm{l}$. Five to seven transverse slices (200 $\mu \mathrm{m}$ in thickness) containing bilateral NM were cut by using a vibratome (Technical Products International, St. Louis, MO). Slices were then equilibrated in oxygenated ACSF at $33-36^{\circ} \mathrm{C}$ for 40-60 min. For recordings, slices were transferred to a $0.5-\mathrm{ml}$ chamber mounted on a Zeiss Axioskop FS (Zeiss, Germany) with a $\times 40$ water-immersion objective and infrared differential interference contrast (IR-DIC) optics and continuously superfused with room temperature $\left(22-23^{\circ} \mathrm{C}\right) \mathrm{ACSF}$ at a rate of $1-2 \mathrm{ml} / \mathrm{min}$. Only one cell from each slice was studied when drugs with irreversible effects were used.

\section{Electrophysiology}

Voltage-clamp experiments were performed with an Axopatch $200 \mathrm{~B}$ and current clamp experiments with an Axoclamp 2B amplifier (Axon Instruments, Foster City, CA). Whole cell $\mathrm{Ca}^{2+}$ channel currents were recorded using barium as the charge carrier $\left(I_{\mathrm{Ba}^{2+}}\right)$. The external solution for recording whole cell $I_{\mathrm{Ba}^{2+}}$ consisted of (in mM) 115 TEA-Cl, $10 \mathrm{BaCl}_{2}, 1 \mathrm{MgCl}_{2}, 5 \mathrm{NaCl}, 3 \mathrm{CsCl}, 10$ HEPES, and 10 glucose, with $\mathrm{pH} 7.4$ adjusted by TEA-OH and osmolarity of $\sim 270$ mosM/l. TEA blocked HVA K ${ }^{+}$channels. The external solution also included tetrodotoxin (TTX, $1 \mu \mathrm{M}$ ) to block $\mathrm{Na}^{+}$channels, 4-aminopyridine (4-AP, $1 \mathrm{mM}$ ) to block LVA ${ }^{+}$channels, bicuculline methiodide $(20-100 \mu \mathrm{M})$ to block spontaneous GABA activity, and 6,7-dinitroquinoxaline-2,3(1H,4H)-dione (DNQX, $50 \mu \mathrm{M})$ and $\mathrm{D}-2-$ amino-5-phosphonovaleric acid (AP-5, $100 \mu \mathrm{M})$ to block non- $N$ methyl-D-aspartate (NMDA) and NMDA receptors, respectively. The external solution was gassed with $100 \%$ oxygen. Patch pipettes were pulled to 1- to $2-\mu \mathrm{m}$ tip diameter and had resistances between 2 and $8 \mathrm{M} \Omega$. To facilitate $\mathrm{G} \Omega$ tight seal formations, the tips of the pipettes were back-filled with (in mM) $140 \mathrm{~K}$-gluconate, 10 HEPES, 5 EGTA, and $1.5 \mathrm{MgCl}_{2}$, with $\mathrm{pH} 7.2$ adjusted by $\mathrm{KOH}$ and osmolarity of 280 mosM/l. The shank of the pipettes was filled with internal solution (in mM) 70 diTris-phosphate, 41 Tris-base, $5 \mathrm{MgCl}_{2}, 10$ EGTA, 0.1 leupeptin, 4 Tris-ATP, 0.2 Tris-GTP, 20 phosphocreatine, and 50 $\mathrm{U} / \mathrm{ml}$ creatine phosphokinase, with $\mathrm{pH} 7.2$ adjusted by $\mathrm{HCl}$ and osmolarity of 270 mosM/l. The junction potential between the external solution and the internal solution was $3 \mathrm{mV}$ and was not corrected in data analyses. After whole cell configuration was achieved by rupturing $\mathrm{G} \Omega$-sealed membrane, series resistance was compensated by $\geq 80 \%$ and then external solution was switched from normal ACSF to the $I_{\mathrm{Ba}^{2+}}$ recording external solution. Generally $I_{\mathrm{Ba}^{2+}}$ recordings were started 5-10 min after whole cell configuration was established. Data were low-pass filtered at $1-2 \mathrm{kHz}$ and digitized with an ITC-16 (Instrutech, Elmont, NY) at $20 \mathrm{kHz}$ for both on- and off-line analyses. All recording protocols were written and run using the Axograph acquisition and analysis software (version 4.5; Axon Instruments). At the beginning of each voltage-pulse protocol, a small hyperpolarizing voltage pulse $(-5 \mathrm{mV}$ in amplitude and $5 \mathrm{~ms}$ in duration) was applied to monitor the series resistance compensation and the input resistance.

To record voltage-gated $\mathrm{Na}^{+}$channel currents $\left(I_{\mathrm{Na}^{+}}\right)$, the recording electrodes were filled with (in $\mathrm{mM}$ ) $150 \mathrm{~N}$-methyl-D-glucamine, 2 $\mathrm{NaCl}, 1 \mathrm{MgCl}_{2}, 10$ EGTA, 40 HEPES, 4 ATP-Na 2 , and $0.2 \mathrm{GTP}-\mathrm{Na}$, with $\mathrm{pH} 7.2$ adjusted by $\mathrm{HCl}$ and osmolarity of $285 \operatorname{mos} \mathrm{M} / \mathrm{l}$. To achieve sufficient voltage clamp, a reduced $\mathrm{NaCl}$ concentration was used in the external solution, which consisted of (in $\mathrm{mM}$ ) $40 \mathrm{NaCl}, 3$ $\mathrm{KCl}, 1 \mathrm{MgCl}_{2}, 2 \mathrm{CaCl}_{2}, 115$ TEA-Cl, 10 HEPES, 10 glucose, 0.4 $\mathrm{CdCl}_{2}$, and 14 -AP, with $\mathrm{pH} 7.4$ adjusted by TEA-OH and osmolarity of $295 \mathrm{mosM} / \mathrm{l}$. The external solution was gassed with $100 \%$ oxygen. The junction potential was $4 \mathrm{mV}$ and was not corrected in data analyses. Cells were held at $-60 \mathrm{mV}$ and a depolarizing voltage command to $-30 \mathrm{mV}$ was applied to activate $I_{\mathrm{Na}^{+}}$. To record voltagegated $\mathrm{K}^{+}$channel currents $\left(I_{\mathrm{K}^{+}}\right)$, the recording electrodes were filled with (in $\mathrm{mM}$ ) $105 \mathrm{~K}$-gluconate, $35 \mathrm{KCl}, 5 \mathrm{EGTA}, 10 \operatorname{HEPES}(\mathrm{K})$, and $1 \mathrm{MgCl}_{2}$, with pH7.2 adjusted with $\mathrm{KOH}$ and osmolarity of 287 mosM/l. In ACSF, TTX $(1 \mu \mathrm{M})$ and $\mathrm{CdCl}_{2}(400 \mu \mathrm{M})$ were included to block $I_{\mathrm{Na}^{+}}$and $I_{\mathrm{Ca} 2+}$. The junction potential was $11 \mathrm{mV}$ and was not corrected in data analyses. Cells were held at $-60 \mathrm{mV}$ and a depolarizing voltage command to $+10 \mathrm{mV}$ was applied to activate $I_{\mathrm{K}^{+}}$. Current-clamp experiments were done using the same internal solution as in $I_{\mathrm{K}^{+}}$recordings.

\section{Data analysis}

The peak values of $I_{\mathrm{Ba}^{2+}}$ during the voltage pulses were measured. For each neuron, the leak current was determined by either of the two following methods: an equation describing the best fit linear currentvoltage $(I-V)$ relation was obtained by stepping to a voltage $20 \mathrm{mV}$ more hyperpolarized than the holding potential $(-50 \mathrm{mV})$ in $5-\mathrm{mV}$ steps, and then the equation was used to calculate the leak current for a specific voltage command (the same method was also used to perform leak subtraction for $I_{\mathrm{Na}^{+}}$and $I_{\mathrm{K}}+$ except that the holding potential for $I_{\mathrm{Na}^{+}}$and $I_{\mathrm{K}^{+}}$was $-60 \mathrm{mV}$ ); or second, leak current was considered as the residual current after applying $\mathrm{CdCl}_{2}(400 \mu \mathrm{M})$ to block all $\mathrm{HVA} \mathrm{Ca}^{2+}$ channels at the end of the experiment. To control for rundown and runup of the currents examined, the amplitude of $I_{\mathrm{Ba}^{2+}}$ obtained before drug application and after washout was averaged and used as the control value for comparisons to the amplitude during drug application (except for Fig. 2 in which the predrug values are used as control values due to the difficulty of washing out the drugs). Percent inhibition of $I_{\mathrm{Ba}^{2+}}$ by different drugs was calculated as $(1-X)^{*} 100$, where $X$ equals $I_{\mathrm{Ba}^{2+}}$ obtained in the test condition divided by the control value. Statistical analyses were done using Abacus Concepts Statview 5.0 and Microsoft Excel 8.0. Means \pm SE along with the number of cells studied $(n)$ are reported unless otherwise indicated.

\section{Drugs and chemicals}

All drugs were bath applied and the standard drug application time was $5 \mathrm{~min}$. In some cases, shorter (2-4 min) or longer (6-8 min) applications were used. (1S,3R)-1-aminocyclopentane-1,3-dicarbosylic acid (1S,3R-ACPD), (RS)-alpha-cyclopropyl-4-phosphonophenylglycine (CPPG), (RS)-alpha-methyl-4-carboxyphenylglycine (MCPG), (RS)-3,5-dihydroxyphenylglycine (3,5-DHPG), (2S, $\left.2^{\prime} \mathrm{R}, 3^{\prime} \mathrm{R}\right)-2-\left(2^{\prime}, 3^{\prime}\right.$-dicarboxycyclopropyl)glycine (DCG-IV), L(+)-2-amino-4-phosphonobutyric acid (L-AP4) were obtained from Tocris Cookson (Ballwin, MO). $\omega$-Agatoxin-IVA ( $\omega$-Aga-IVA) was obtained from Peptides International (Louisville, KY). Chemicals and other drugs including 1,4-dihy- 
dro-2,6-dimethyl-4-[3-nitrophenyl]-3,5-pyridinedicarboxylic acid 2-methoxyethyl-1-methylethyl ester (nimodipine), 1,4-dihydro2,6-dimethyl-4-(2-nitrophenyl)-3,5-pyridinedicarboxylic acid dimethyl ester (nifedipine), 2,5-dimethyl-4-[2-(phenylmethyl)benzoyl]1H-pyrrole-3-carboxlic acid methyl ester (FPL 64176), $\omega$-conotoxinGVIA ( $\omega$-CTx-GVIA), L-glutamic acid (glutamate), some 1S,3RACPD, TTX, bicuculline methiodide, DNQX, AP-5, and 4-AP were obtained from Sigma (St Louis, MO). Some TEA-Cl was obtained from B.J. Baker (Phillipsburg, NJ).

\section{R E S U L T S}

\section{Global $\mathrm{I}_{\mathrm{Ba}^{2+}}$ of NM neurons}

We recorded whole cell VGCC currents of NM neurons under voltage-clamp conditions after blocking voltage-gated $\mathrm{Na}^{+}$and $\mathrm{K}^{+}$conductances. Both LVA and HVA $I_{\mathrm{Ba}^{2+}}$ were observed, similar to what has been reported previously (Koyano et al. 1996). The LVA and HVA I-Ba ${ }^{2+}$ were distinguished from each other physiologically. Figure $1 A$ shows six superimposed individual current traces from a representative NM neuron in response to voltage steps from the holding potential of $-90 \mathrm{mV}$. When the cell was held at $-50 \mathrm{mV}$ (Fig. $1 \mathrm{~B})$, the LVA component was inactivated and the HVA $I_{\mathrm{Ba}^{2+}}$ was recorded in response to depolarizing steps. The LVA $I_{\mathrm{Ba}^{2+}}$ was rapidly inactivating and the HVA $I_{\mathrm{Ba}^{2+}}$ was noninactivating under our recording conditions (100 ms depolarizing steps). Extracellular $\mathrm{Ba}^{2+}$ can block $\mathrm{K}^{+}$channels, argument currents via $\mathrm{Ca}^{2+}$ channels, and help achieve sufficient voltage clamp, but does not support $\mathrm{Ca}^{2+}$-dependent inactivation of $\mathrm{Ca}^{2+}$ channels (Hille 2001). When using $\mathrm{Ca}^{2+}$ as the charge carrier, we observed a LVA $I_{\mathrm{Ca} 2+}$ with similar kinetics to LVA $I_{\mathrm{Ba}^{2+}}$ (data not shown), indicating that the inactivation of the LVA $\mathrm{Iaa}^{2+}$ is not due to $\mathrm{Ca}^{2+}$-dependent inactivation of $\mathrm{Ca}^{2+}$ channels. Due to its kinetics and sensitivity to low concentration of $\mathrm{Ni}^{+}$, the LVA $I_{\mathrm{Ba}^{2+}}$ might be a T-type $\mathrm{Ca}^{2+}$ channel current (Koyano et al. 1996).

Figure $1 C$ shows the average current-voltage $(I-V)$ relation ( $n=5$ cells) of the total peak $I_{\mathrm{Ba}^{2+}}$. The total $I_{\mathrm{Ba}^{2+}}$ was observed at potentials more depolarizing than $-55 \mathrm{mV}$ and peaked at $-15 \mathrm{mV}$. Figure $1 D$ shows the average $I-V$ relation of the peak HVA $I_{\mathrm{Ba}^{2+}}$. The HVA $I_{\mathrm{Ba}^{2+}}$ was observed at potentials more depolarizing than $-40 \mathrm{mV}$ and peaked at $-10 \mathrm{mV}$. Average data of the total $I_{\mathrm{Ba}^{2+}}$ were plotted and fitted to a Boltzmann relationship of the form $I / I_{\max }=1 /\left[1+\exp \left(V_{\mathrm{h}}-\right.\right.$ $V) / \mathrm{k}$, giving a half activation $\left(V_{\mathrm{h}}\right)$ of $-33 \mathrm{mV}$ and a slope $(k)$ of $8 \mathrm{mV}$ (Fig. $1 E$ ). Average data of the HVA $I_{\mathrm{Ba}^{2+}}$ were fitted to the Boltzmann relationship with a $V_{\mathrm{h}}$ of $-24 \mathrm{mV}$ and a slope of $4 \mathrm{mV}$ (Fig. 1F).

Rundown of the $\mathrm{Ca}^{2+}$ channel currents, especially the HVA component, is a common observation. Some previous studies have attempted to determine the factors, such as ATP, magnesium, and calpastatin (an inhibitor of the $\mathrm{Ca}^{2+}$-activated protease calpain), that influence the rundown process (Byerly and Yazejian 1986; Hao et al. 1999). Although ATP, magnesium, an ATP regenerating solution, and a protease inhibitor (leupeptin) were included in our internal solution, some rundown usually persisted. To quantify the typical rundown of the HVA $\mathrm{IBa}^{2+}$ in NM neurons, we measured the current once every $20 \mathrm{~s}$ for $25 \mathrm{~min}$ without any manipulations in a sample of cells. The averaged current decreased by $<20 \%$ in 25 min (data not shown). Run-up of the HVA $I_{\mathrm{Ba}^{2+}}$ in the
A

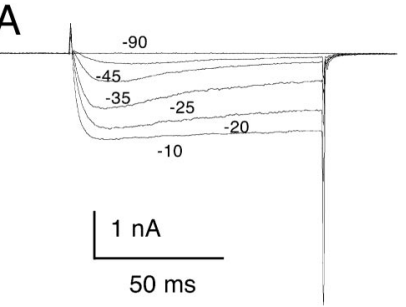

B
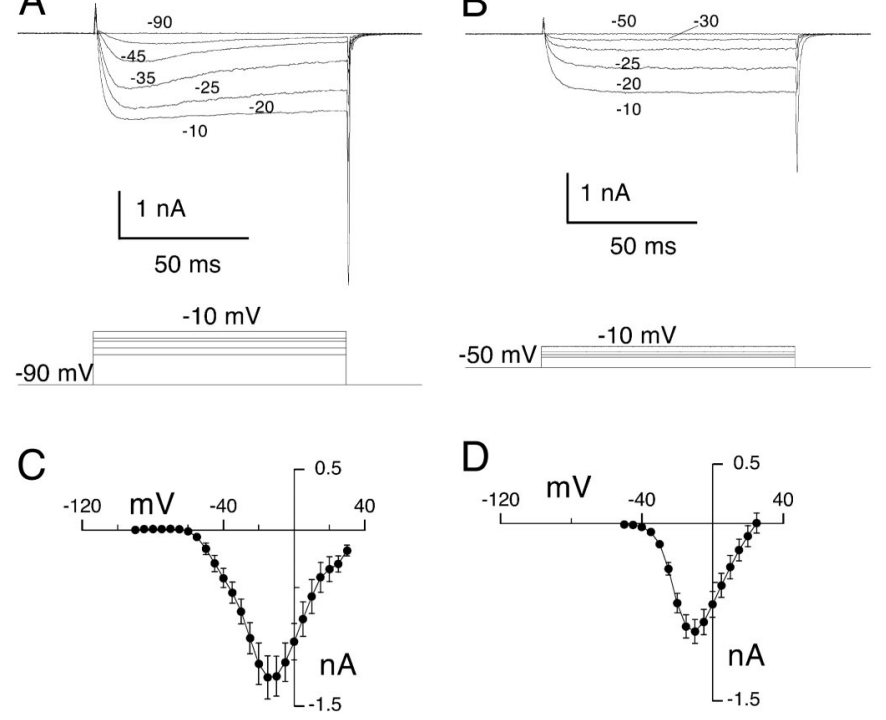

$\mathrm{E}$
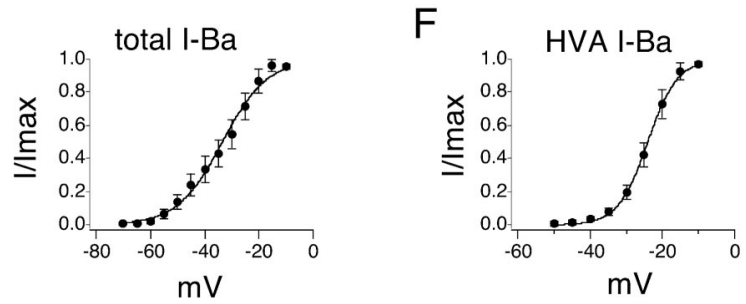

FIG. 1. Whole cell barium currents $\left(I_{\mathrm{Ba}^{2+}}\right)$ through $\mathrm{Ca}^{2+}$ channels of nucleus magnocellularis (NM) neurons. In all experiments, 6,7-dinitroquinoxaline-2,3(1H,4H)-dione (DNQX, $50 \mu \mathrm{M})$, D-2-amino-5-phosphonovaleric acid (AP-5, $100 \mu \mathrm{M})$, and bicuculline $(20 \mu \mathrm{M})$ were included in the external recording solution to block spontaneous synaptic currents. $A$ : 6 superimposed current traces obtained by voltage steps to $-90,-45,-35,-25,-20$, and -10 $\mathrm{mV}$ from the holding potential of $-90 \mathrm{mV}$. The 1 st trace serves as the baseline. $B$ : the same cell shown in $A$ was held at $-50 \mathrm{mV}$ to inactivate the low-voltageactivated (LVA) $I_{\mathrm{Ba}^{2+}}$. Five individual current traces in response to voltage steps from -50 to $-50,-30,-25,-20$, and $-10 \mathrm{mV}$ are superimposed. The high-voltage-activated (HVA) $I_{\mathrm{Ba}^{2+}}$ was noninactivating under our recording conditions (100-ms depolarizing pulses). $C$ and $D$ : average current-voltage $(I-V)$ relations ( $n=5$ cells) of the total peak $I_{\mathrm{Ba}^{2+}}$ and the peak $\mathrm{HVA} I_{\mathrm{Ba}^{2+}}$. The HVA $I_{\mathrm{Ba}^{2+}}$ was observed at potentials more depolarizing than $-40 \mathrm{mV}$ and peaked at $-10 \mathrm{mV}$. E: average data of the total $I_{\mathrm{Ba}^{2+}}$ were plotted and fitted to a Boltzmann relationship of the form $I / I_{\max }=1 /\left[1+\exp \left(V_{\mathrm{h}}-V\right) / k\right]$, giving a half activation $\left(V_{\mathrm{h}}\right)$ of $-33 \mathrm{mV}$ and a slope $(k)$ of $8 \mathrm{mV}$. $F$ : average data of the HVA $I_{\mathrm{Ba}^{2+}}$ were fitted to the Boltzmann relationship with a $V_{\mathrm{h}}$ of $-24 \mathrm{mV}$ and a slope of $4 \mathrm{mV}$. Bars represent means $\pm \mathrm{SE}$.

beginning of the recordings was observed in a small sample of cells.

\section{Types of HVA VGCCs in NM neurons}

Pharmacological experiments using selective $\mathrm{Ca}^{2+}$ channel inhibitors were carried out to determine the type(s) of HVA VGCCs in NM neurons and how much each current contributes to the total HVA $I_{\mathrm{Ba}^{2+}}$ (Fig. 2). Nimodipine (10 $\left.\mu \mathrm{M}\right), \omega$-conotoxin-GVIA $(\omega$-CTx-GVIA, $1 \mu \mathrm{M})$, and $\omega$-agatoxin-IVA $(\omega$ Aga-IVA, $100 \mathrm{nM}$ ) were used to block L-, N-, and P/Q-type HVA VGCCs, respectively. The residual current resistant to a cocktail of all three inhibitors is designated as R-type $I_{\mathrm{Ba}^{2+}}$. HVA $I_{\mathrm{Ba}^{2+}}$ was recorded by applying a voltage step to $-10 \mathrm{mV}$ from the holding potential of $-50 \mathrm{mV}$ once every $20 \mathrm{~s} . \mathrm{I}_{\mathrm{Ba}^{2+}}$ values in this and subsequent figures are the absolute values 

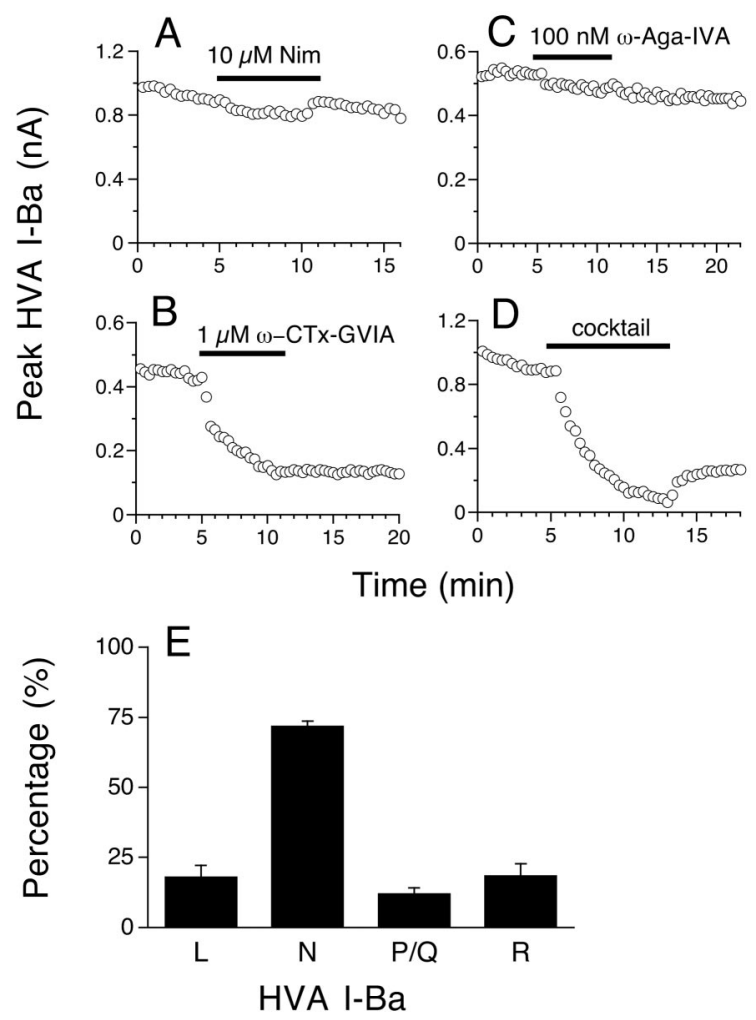

FIG. 2. Effects of L-, N-, P/Q-type $\mathrm{Ca}^{2+}$ channel inhibitors on $\mathrm{HVA} \mathrm{I}_{\mathrm{Ba}^{2+}}$ of NM neurons. Peak HVA $I_{\mathrm{Ba}^{2+}}$ generated by a voltage step to $-10 \mathrm{mV}$ from the holding potential of $-50 \mathrm{mV}$ was plotted against time. Note that in this and subsequent figures, the plots show the absolute values of $I_{\mathrm{Ba}^{2+}}$, and the time point of $0 \mathrm{~min}$ represents $5-10 \mathrm{~min}$ after accessing whole cell configuration. $A-D$ : effects of application of nimodipine $(10 \mu \mathrm{M}), \omega$-CTx-GVIA $(1 \mu \mathrm{M})$, $\omega$-Aga-IVA $(100 \mathrm{nM})$, and a cocktail containing all 3 blockers on the peak HVA $I_{\mathrm{Ba}^{2+}}$ in 4 different NM neurons. Note that each drug blocked a portion of the HVA $I_{\mathrm{Ba}^{2+}}$. Nimodipine, but not $\omega$-CTx-GVIA or $\omega$-Aga-IVA was washed out, and the cocktail did not block the HVA $I_{\mathrm{Ba}^{2+}}$ completely. $E$ : pooled data $\left(n=4,6,5,5\right.$ cells for L-, N-, P/Q-, and R-type HVA $I_{\mathrm{Ba}^{2+}}$, respectively) show that $\omega$-CTx-GVIA-sensitive (N-type) currents dominate in $\mathrm{NM}$ neuron. Bars represent means $\pm \mathrm{SE}$.

and the zero time point represents 5-10 min after accessing whole cell configuration. We applied only one of the blockers or only the cocktail of all three blockers to any one cell. Because of the difficulty of washing out some of the blockers, we recorded only one cell from each brain slice to avoid drug contamination.

Predrug recordings were obtained for 5 min. Nimodipine (10 $\mu \mathrm{M})$, a dihydropyridine compound which is a selective L-type $\mathrm{Ca}^{2+}$ channel blocker (McCarthy and TanPiengco 1992; Randall and Tsien 1995), blocked a small fraction of the HVA $I_{\mathrm{Ba}^{2+}}$ and the blocker was readily washed out (Fig. 2A). $\omega$-CTxGVIA $(1 \mu \mathrm{M})$, a cone snail toxin that blocks the N-type $\mathrm{Ca}^{2+}$ channels irreversibly (Aosaki and Kasai 1989; Boland et al. 1994; Randall and Tsien 1995; Regan 1991), blocked more than half of the total HVA $\mathrm{IBa}^{2+}$, indicating that N-type HVA $I_{\mathrm{Ba}^{2+}}$ is the dominant component of the total HVA $I_{\mathrm{Ba}^{2+}}$ in NM neurons (Fig. 2B). $\omega$-Aga-IVA (100 nM), a P/Q-type $\mathrm{Ca}^{2+}$ channel blocker, generated a small reduction of the HVA $I_{\mathrm{Ba}^{2+}}$. P/Q-type $I_{\mathrm{Ba}^{2+}}$ was small and the two components (P and Q type) were not further distinguished. The percentage of each type HVA $I_{\mathrm{Ba}^{2+}}$ of the total HVA $I_{\mathrm{Ba}^{2+}}$ was calculated as the fraction of the $I_{\mathrm{Ba}^{2+}}$ at the end of each channel blocker application of the total $I_{\mathrm{Ba}^{2+}}$ measured before any blocker applica- tion. The cocktail did not block the HVA $I_{\mathrm{Ba}^{2+}}$ completely, suggesting the existence of R-type $I_{\mathrm{Ba}^{2+}}$ conductance (Fig. $2 D$, note the washout of nimodipine in this figure as well as in $A$ ). The percentages of each type HVA $I_{\mathrm{Ba}^{2+}}$ calculated from these experiments were $17.9 \pm 4.2 \%(n=4$ cells $), 71.7 \pm 1.9 \%$ $(n=6$ cells $), 11.9 \pm 2.2 \%(n=5$ cells $)$, and $18.3 \pm 4.4 \%(n=$ 5 cells) for L, N, P/Q, and R type, respectively (Fig. $2 E$ ). The sum of the four percentages was slightly over $100 \%$, presumably due to nonspecific blocking and different rundown rates of the currents in different cells.

The validity of the conclusions presented in the preceding text (and in the following text) depends on the effectiveness of the $\mathrm{Ca}^{2+}$ channel blockers on NM neurons; the concentration of each blocker we used should have been able to completely and selectively block a specific type of HVA VGCCs. We confirmed the effectiveness of each blocker in the following experiments (Fig. 3). We used FPL $64176(2 \mu \mathrm{M})$ to test the effectiveness of nimodipine $(10 \mu \mathrm{M})$ on blocking L-type channels. FPL 64176 is an effective L-type channel activator, which acts at a site different from the binding site of dihydropyridine compounds (Zheng et al. 1991). As shown in Fig. $3 A(n=3$ cells), FPL 64176 enhanced the HVA $I_{\mathrm{Ba}^{2+}}$ in the absence of nimodipine, with possibly high rundown during a short period after the enhancement reached the peak. This accelerated rundown might be expected when L-type channels are fully activated by FPL 64176 due to the fact that maintenance of $\mathrm{Ca}^{2+}$ channels requires many factors. Note that by $\sim 1 \mathrm{~min}$ after termination of FPL 64176 application the rundown rate returned to about the same as before drug application. When nimodipine $(10 \mu \mathrm{M})$ was included in the bath, the enhance-

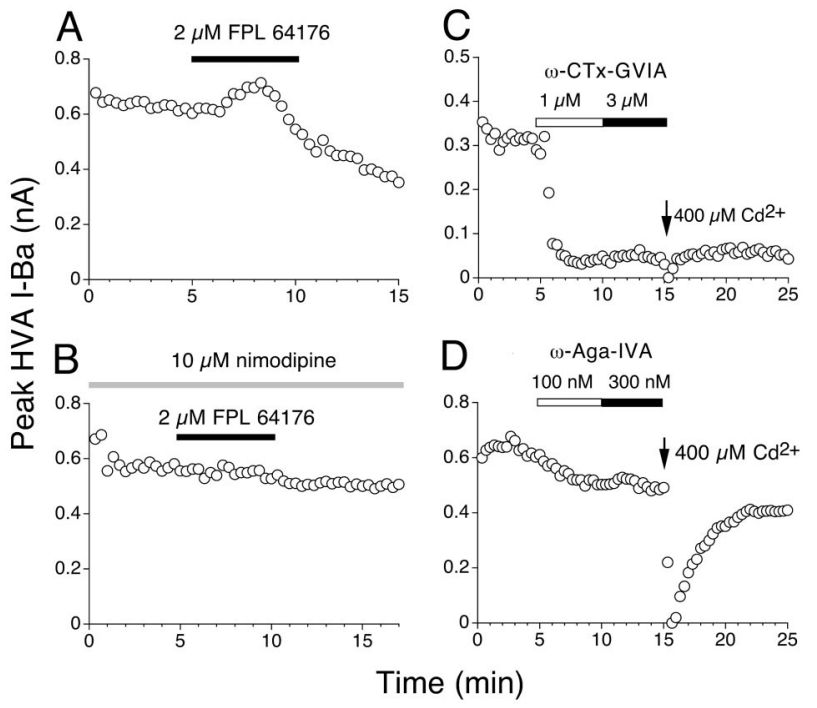

FIG. 3. Further confirmation of effectiveness of L-, N-, P/Q-type $\mathrm{Ca}^{2+}$ channel blockers. A: FPL $64176(2 \mu \mathrm{M})$, an L-type channel activator, was used to test the effectiveness of nimodipine $(10 \mu \mathrm{M})$ for blocking L-type channels. FPL 64176 enhanced the HVA $I_{\mathrm{Ba}^{2+}}(n=3$ cells $) . B$ : in the presence of nimodipine (long gray bar on the top of the graph), FPL 64176 no longer enhanced the HVA $I_{\mathrm{Ba}^{2+}}(n=3$ cells $)$. Note the reduction of HVA $I_{\mathrm{Ba}^{2+}}$ by nimodipine in the beginning of the recording. $C$ : effects of successive application of $\omega$-CTx-GVIA $(1$ and $3 \mu \mathrm{M})$ on HVA $I_{\mathrm{Ba}^{2+}}$. Application of $\omega$-CTxGVIA $(1 \mu \mathrm{M})$ largely inhibited the HVA $I_{\mathrm{Ba}^{2+}}$ and increasing the concentration of the toxin by threefold did not further block the HVA $I_{\mathrm{Ba}^{2+}}(n=3$ cells). $D$ : effects of successive application of $\omega$-Aga-IVA (100 and $300 \mathrm{nM}$ ) on HVA $I_{\mathrm{Ba}^{2+}}$. Application of $\omega$-Aga-IVA $(100 \mathrm{nM})$ inhibited the HVA $I_{\mathrm{Ba}^{2+}}$ and a threefold concentration increase did not result in more inhibition $(n=5$ cells). 
ment of $I_{\mathrm{Ba}^{2+}}$ by FPL $64176(2 \mu \mathrm{M})$ was abolished (Fig. $3 B$, $n=3$ cells), indicating that L-type channel $I_{\mathrm{Ba}^{2+}}$ of NM neurons could be completely blocked by nimodipine $(10 \mu \mathrm{M})$. To test the effectiveness of $\omega$-CTx-GVIA $(1 \mu \mathrm{M})$ and $\omega$-AgaIVA $(100 \mathrm{nM})$ on $\mathrm{N}-$ and P/Q- type $\mathrm{Ca}^{2+}$ channels, respectively, we tripled the concentration of each blocker successively for $5 \mathrm{~min}$ after the original concentration was applied for $5 \mathrm{~min}$. Neither blocker at their tripled concentration produced additional effectiveness (Fig. 3, $C, n=3$ cells, and $D, n=5$ cells), indicating that $\mathrm{N}$ - and P/Q-type HVA currents were maximally blocked under our experimental conditions. Therefore we feel confident that the concentrations of each blocker used in the experiments presented in the following text is appropriate to assess the type(s) of HVA VGCCs modulated by mGluR activation.

\section{Activation of mGluRs inhibits HVA $I_{B a^{2+}}$ of NM neurons}

Figure $4 A$ shows an example in which glutamate $(100 \mu \mathrm{M}$, in the presence of iGluR antagonists DNQX and AP-5) inhibited HVA $I_{\mathrm{Ba}^{2+}}$ of a NM neuron. The inhibitory effect developed fully at $\sim 1 \mathrm{~min}$ after glutamate application and decreased over time in the presence of continued glutamate, possibly due to desensitization of mGluRs (Aronica et al. 1993; Catania et al. 1991; Kammermeier and Ikeda 2002).

Figure $4 B$ shows the relationship between inhibition of HVA $I_{\mathrm{Ba}^{2+}}$ and glutamate concentration. Glutamate $(1 \mu \mathrm{M})$ had no effect on HVA $I_{\mathrm{Ba}^{2+}}(n=6$ cells). Glutamate at concentrations of 10,100 , and $500 \mu \mathrm{M}$, inhibited the HVA $I_{\mathrm{Ba}^{2+}}$ by $6.8 \pm$ $1.5 \%(n=4$ cells $), 16.3 \pm 3.1 \%(n=18$ cells $)$, and $15.9 \pm$ $4.9 \%(n=5$ cells $)$, respectively. One-way ANOVA showed a
A

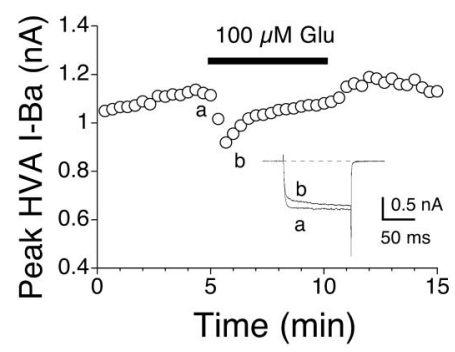

$\mathrm{D}_{1}$
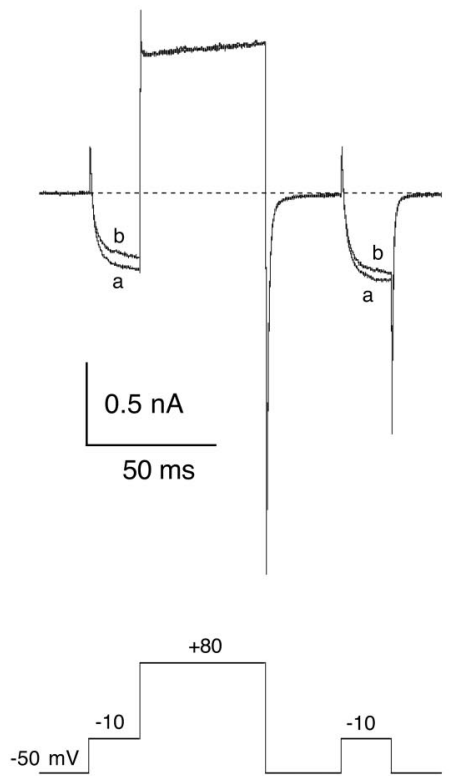

$\mathrm{B}$

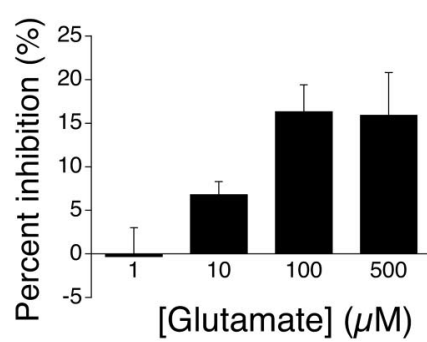

$\mathrm{D}_{2}$

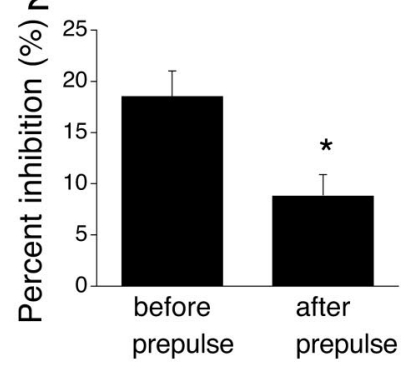

$\mathrm{F}$

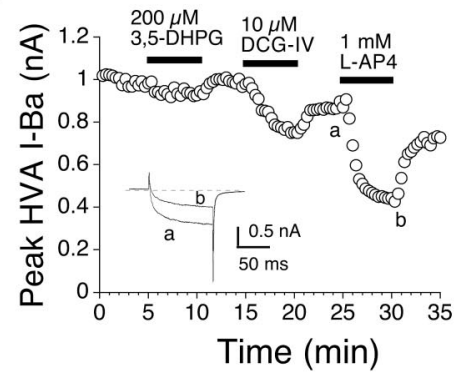

C

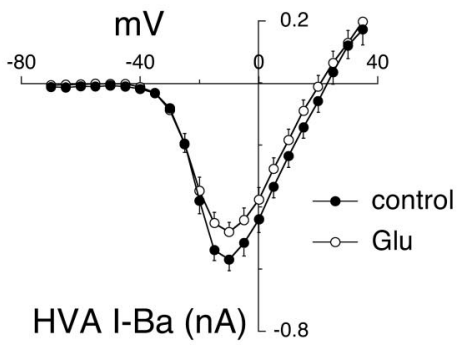

E

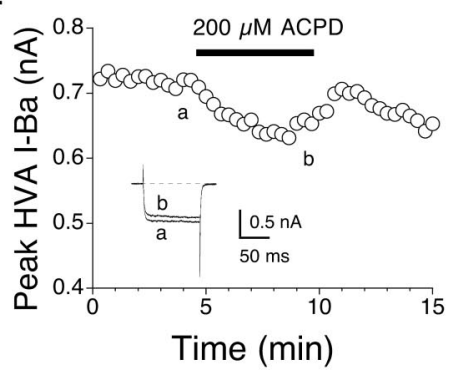

G

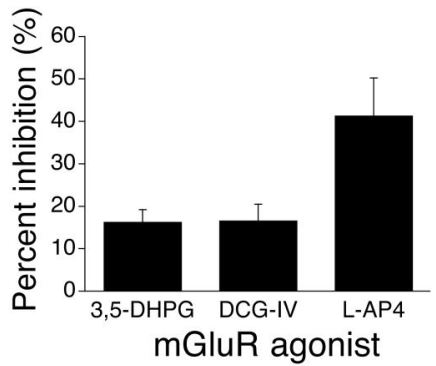

FIG. 4. Activation of mGluRs inhibits HVA $I_{\mathrm{Ba}^{2+}}$ of NM neurons. A: suppression of HVA $I_{\mathrm{Ba}^{2+}}$ by glutamate (100 $\left.\mu \mathrm{M}\right)$ application in the presence of DNQX $(50 \mu \mathrm{M})$ and AP-5 $(100 \mu \mathrm{M}, n=18$ cells). Two individual current traces obtained before and during glutamate application are shown as insets. Inhibition of the HVA $I_{\mathrm{Ba}^{2+}}$ by glutamate shows desensitization. $B$ : concentration-response of glutamate-mediated inhibition of $\mathrm{HVA} I_{\mathrm{Ba}^{2+}}$. Average data at each concentration were obtained from 4 to 18 cells. $C$ : average $I$ - $V$ relations of the HVA $I_{\mathrm{Ba}^{2+}}$ under control and glutamate $(100 \mu \mathrm{M})$ application show that the inhibition appeared to be voltage-dependent ( $n=7$ cells); little or no inhibition was seen at potentials more negative than $-25 \mathrm{mV}$. $D$ : glutamate (100 $\mu \mathrm{M})$-mediated inhibition of the HVA $I_{\mathrm{Ba}^{2+}}$ was relieved by a depolarizing prepulse $(+80 \mathrm{mV}$, duration of $50 \mathrm{~ms})$. The voltage protocol and 2 averaged traces (a: before prepulse; b: after repulse) are shown as an example $(D 1)$. Pooled data show significant reduction in percent inhibition after prepulse compared with before prepulse $(D 2, n=5$ cells, $P<0.05)$. E: example showing inhibition of HVA $I_{\mathrm{Ba}^{2+}}$ was mimicked by $1 \mathrm{~S}, 3 \mathrm{R}-\mathrm{ACPD}(200 \mu \mathrm{M})$, a mGluR agonist. This was repeated on $11 \mathrm{NM}$ neurons. $F$ : an example showing that activation of group I-III mGluRs by (RS)-3,5-dihydroxyphenylglycine (3,5-DHPG; 200 $\mu \mathrm{M}),\left(2 \mathrm{~S}, 2^{\prime} \mathrm{R}, 3^{\prime} \mathrm{R}\right)-2-\left(2^{\prime}, 3^{\prime}-\right.$ dicarboxycyclopropyl)glycine (DCG-IV; $10 \mu \mathrm{M}$ ), and L(+)-2-amino-4-phosphonobutyric acid (L-AP4; $1 \mathrm{mM}$ ) inhibited the HVA $I_{\mathrm{Ba}^{2+}}$. $G$ : mean percent inhibition of the HVA $I_{\mathrm{Ba}^{2+}}$ in response to group I-III mGluR agonists $(n=9,8,8$ cells, respectively). Bars represent means \pm SE. 
significant effect of glutamate concentration on the percent inhibition of HVA $I_{\mathrm{Ba}^{2+}}[F(3,29)=3.685, P<0.05)$. Post hoc Fisher's test showed significant differences between the treatment of 1 and $100 \mu \mathrm{M}(P<0.01)$ and 1 and $500 \mu \mathrm{M}(P<$ $0.05)$. The response appeared to be saturated at $100 \mu \mathrm{M}$ because glutamate $(500 \mu \mathrm{M})$ produced no further inhibition of HVA $I_{\mathrm{Ba}^{2+}}$. Results of inhibition of HVA $I_{\mathrm{Ba}^{2+}}$ by higher glutamate concentration $(1 \mathrm{mM})$ are not reported because this concentration of glutamate depolarized NM cells and decreased the input resistance, even in the presence of DNQX and AP-5 ( $n=6$ cells). The inhibition appeared to be voltage dependent (Fig. $4 C, n=7$ cells), with little or no inhibition occurring at potentials more negative than $-25 \mathrm{mV}$. Figure $4 D$ shows that a depolarizing prepulse $(+80 \mathrm{mV}$, duration of 50 $\mathrm{ms})$ relieved the inhibition. Glutamate $(100 \mu \mathrm{M})$ inhibited the current by $18.5 \pm 2.5$ and $8.8 \pm 2.1 \%$ before and after the prepulse, respectively $(P<0.05, n=5$ cells). These results are consistent with previous reports on G-protein-coupled neurotransmitter receptors (e.g., Bean 1989; Choi and Lovinger 1996; Sahara and Westbrook 1993; Swartz and Bean 1992). 1S,3R-ACPD, a nonspecific mGluR agonist, mimicked the inhibitory effect of glutamate on HVA $I_{\mathrm{Ba}^{2+}}$ (Fig. 4E). 1S,3RACPD $(200 \mu \mathrm{M})$ inhibited HVA $I_{\mathrm{Ba}^{2+}}$ by an average of $12.4 \pm$ $3.2 \%(n=11$ cells $)$.

The inhibition of HVA $I_{\mathrm{Ba}^{2+}}$ by glutamate was not blocked by iGluR antagonists; DNQX $(50 \mu \mathrm{M})$ and AP-5 $(100 \mu \mathrm{M})$ were present in the recording solutions in all experiments, further supporting the conclusion that mGluRs mediated this inhibition. MCPG is reported to be a competitive antagonist of group I and II mGluRs, but not group III (Hayashi et al. 1994). Somewhat surprisingly, MCPG $(1 \mathrm{mM})$ failed to block the inhibitory effect of glutamate $(100 \mu \mathrm{M})$ on HVA $I_{\mathrm{Ba}^{2+}}$ (data not shown). Similar findings have been reported in other neuron types. For example, in neurons of the medial nucleus of the trapezoid body (MNTB), 1S,3S-ACPD (20-50 $\mu \mathrm{M})$, another nonspecific mGluR agonist, reduces the probability of transmitter release and the effect is not antagonized by MCPG at the concentration of $0.5-1 \mathrm{mM}$ (Barnes-Davies and Forsythe 1995). Similarly, in cortical neurons, MCPG $(1 \mathrm{mM})$ only partially blocks $1 \mathrm{~S}, 3 \mathrm{R}$-ACPD $(50 \mu \mathrm{M})$-mediated inhibition of HVA Ca ${ }^{2+}$ currents (Sayer 1998).

We assessed the contribution of each mGluR group using specific group agonists. Figure $4 F$ shows an example in which group I agonist 3,5-DHPG $(200 \mu \mathrm{M})$, group II agonist DCG-IV $(10 \mu \mathrm{M})$, and group III agonist L-AP4 $(1 \mathrm{mM})$ were applied sequentially during the recording of HVA $I_{\mathrm{Ba}^{2+}}$ of a NM neuron. The order of the application of the agonists was varied in different cells. The concentrations of 3,5-DHPG, DCG-IV, and L-AP4 are 3, 33, and 10 times higher than their $\mathrm{EC}_{50}$ obtained from cell lines, respectively, so that all members in each mGluR group can be activated regardless of their potency, and the agonists are reported to have minimal cross-talk (reviewed in Cartmell and Schoepp 2000; Conn and Pin 1997). As seen in Fig. $4 F$, each mGluR group agonist inhibited the HVA $I_{\mathrm{Ba}^{2+}}$ of the sample NM neuron. The slow kinetics of HVA $I_{\mathrm{Ba}^{2+}}$ shown in the inset is not typical of our recording and was likely due to residual inhibition from earlier application of groups I and II agonists. The kinetics of the currents prior to any drug application was faster than the traces shown in the inset to Fig. $4 F$ (data not shown). Other investigators have also reported that inhibition of $\mathrm{Ca}^{2+}$ channels, particularly $\mathrm{N}$-type channels, by neurotransmitter receptors via a voltage- and G-proteindependent mechanism, distorts channel activation kinetics (e.g., Choi and Lovinger 1996; Garcia-Ferreiro et al. 2001; Lambert and Wilson 1996). The average percent inhibition of HVA $I_{\mathrm{Ba}^{2+}}$ by group I-III mGluR agonists was $16.2 \pm 3.0$, $16.5 \pm 4.0$, and $41.2 \pm 9 \%$, respectively (Fig. $4 G ; n=9,8$, and 8 cells, respectively, for group I-III mGluR agonists). One-way ANOVA showed significant difference in the effect of group I-III mGluR agonists on HVA $I_{\mathrm{Ba}^{2+}}[F(2,22)=6.059$, $P<0.01]$. Post hoc Fisher's test showed significant difference between the treatment of 3,5-DHPG and L-AP4 $(P<0.01)$, and DCG-IV and L-AP4 $(P<0.01)$ but not between 3,5-DHPG and DCG-IV $(P>0.5)$. Because L-AP4 $(1 \mathrm{mM})$ produced the largest inhibition, we further examined the effects on HVA $I_{\mathrm{Ba}^{2+}}$ of L-AP4 at two smaller doses $(1$ and $100 \mu \mathrm{M})$. L-AP4 at a concentration of $100 \mu \mathrm{M}$ inhibited the $\mathrm{HVA} I_{\mathrm{Ba}^{2+}}$ by $11.2 \pm$ $3.1 \%(n=6$ cells $)$, while L-AP4 at a concentration of $1 \mu \mathrm{M}$ produced little changes $(1.9 \pm 1.3 \%)$ of the current $(n=5$ cells). However, glutamate $(100 \mu \mathrm{M})$-mediated inhibition of the HVA $I_{\mathrm{Ba}^{2+}}$ was marginally blocked by CPPG $(5 \mu \mathrm{M})$, a group III mGluR antagonist. The percent inhibition was $14.9 \pm$ 3.4 and $12.3 \pm 2.4 \%$ in the absence and presence of CPPG ( $n=4$ cells, data not shown), suggesting that nonspecific effects of L-AP4 especially at high concentration $(1 \mathrm{mM})$ might be present.

Which type(s) of HVA $\mathrm{IBa}^{2+}$ are inhibited?

Glutamate-mediated inhibition of HVA $I_{\mathrm{Ba}^{2+}}$ was examined in the absence and presence of $\omega$-CTx-GVIA $(1 \mu \mathrm{M}, n=5$ cells). In Fig. 5, we report the total HVA $I_{\mathrm{Ba}^{2+}}$ that is inhibited by glutamate $(100 \mu \mathrm{M})$ and the percent inhibition when the
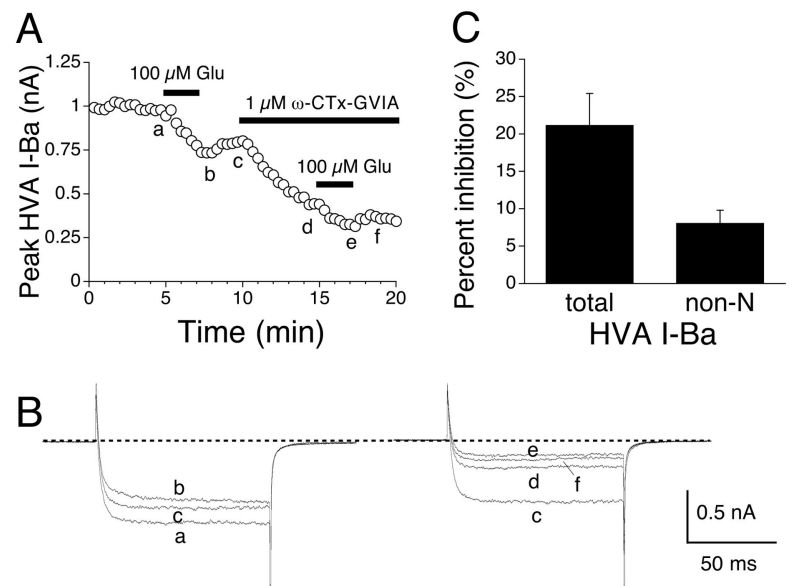

FIG. 5. Effects of N-type channel blocker $\omega$-CTX-GVIA on glutamatemediated inhibition of HVA $I_{\mathrm{Ba}^{2+}}$. A: an example showing the suppression of HVA $I_{\mathrm{Ba}^{2+}}$ by glutamate $(100 \mu \mathrm{M})$ before and after the $\mathrm{N}$-type channels were blocked by $\omega$-CTx-GVIA $(1 \mu \mathrm{M})$. The 1st glutamate application inhibited the HVA $I_{\mathrm{Ba}^{2+}}$ by $16.0 \%$. After $\omega$-CTX-GVIA $(1 \mu \mathrm{M})$ was applied for $5 \mathrm{~min}$, the 2nd application of glutamate resulted in less inhibition of the HVA $\mathrm{Baa}^{2+}$ $(10.9 \%)$. Note that 3 stable current traces (duration of $1 \mathrm{~min}$ ) were obtained prior to the 2nd glutamate application. $B: 2$ groups of superimposed individual current traces taken at times indicated by a-f in $A$. C: Glutamate $(100 \mu \mathrm{M})$ inhibited the total HVA $I_{\mathrm{Ba}^{2+}}$ by $21.1 \%(n=5$ cells $)$. In the presence of $\omega$-CTX-GVIA, glutamate inhibited the non-N-type HVA $I_{\mathrm{Ba}^{2+}}$ by $8.0 \%$. The percent inhibition of N-type HVA $I_{\mathrm{Ba}^{2+}}(13.1 \%)$ was calculated by using the total percent inhibition minus percent inhibition in the presence of $\omega$-CTXGVIA. Bars represent means $\pm \mathrm{SE}$. 
N-type $I_{\mathrm{Ba}^{2+}}$, the most dominant component, is blocked by $\omega$-CTX-GVIA $(1 \mu \mathrm{M})$. Figure $5 A$ shows an example of these experiments. After $\omega$-CTx-GVIA $(1 \mu \mathrm{M})$ was applied for 5 min to block N-type $\mathrm{Ca}^{2+}$ channels (and in the continued presence of $\omega$-CTx-GVIA), the second application of glutamate $(100 \mu \mathrm{M})$ produced less inhibition of HVA $I_{\mathrm{Ba}^{2+}}$ compared with the first application of the agonist. Note that three stable current traces (duration of $1 \mathrm{~min}$ ) were obtained prior to the second glutamate application, indicating that blocking of $\mathrm{N}$-type channels reached a relatively stable condition. Figure $5 B$ shows two groups of individual current traces before, during, and after glutamate application; taken at the times indicated by a-f in Fig. 5A. Traces a-c were obtained in the absence of $\omega$-CTx-GVIA and traces $\mathrm{d}-\mathrm{f}$ in the presence of $\omega$-CTx-GVIA. The difference between traces $\mathrm{c}$ and d estimates the amount of the N-type HVA $I_{\mathrm{Ba}^{2+}}$ blocked by $\omega$-CTx-GVIA. The HVA $I_{\mathrm{Ba}^{2+}}$ that was inhibited by application of glutamate $(100 \mu \mathrm{M})$ in the presence of $\omega$-CTx-GVIA was presumably non-N-type HVA $I_{\mathrm{Ba}^{2+}}$. The average results $(n=5$ cells $)$ are shown in Fig. 5C. The average percent inhibition of the total HVA $I_{\mathrm{Ba}^{2+}}$ was $21.1 \pm 4.3 \%$ and that contributed by non-Ntype HVA $I_{\mathrm{Ba}^{2+}}$ was $8.0 \pm 1.8 \%$ (relative to the total HVA $I_{\mathrm{Ba}^{2+}}$ under control condition, measured as the average of predrug and washout conditions to account for rundown and in this case incomplete recovery of glutamate's effects, see METHODS). The percent inhibition of N-type $I_{\mathrm{Ba}^{2+}}$ is therefore estimated to be $13.1 \%$. Both N-type and non-N-type $I_{\mathrm{Ba}^{2+}}$ were inhibited by mGluR activation.

\section{$1 S, 3 R-A C P D$ did not modify $\mathrm{I}_{a^{+}}$or $\mathrm{I}_{K^{+}}$nor the firing properties of NM neurons}

Figure $6 A$ shows that $1 \mathrm{~S}, 3 \mathrm{R}-\mathrm{ACPD}(200 \mu \mathrm{M})$ did not alter $I_{\mathrm{Na}^{+}}$recorded by using a $100 \mathrm{~ms}$ depolarization pulse stepping from -60 to $-30 \mathrm{mV}(n=5$ cells, $1.12 \pm 0.15$ and $1.10 \pm 0.13$ $\mathrm{nA}$ for control and 1S,3R-ACPD, respectively; paired $t$-test $P>0.05)$. In addition, the total $I_{\mathrm{K}^{+}}$, recorded by using a 100 ms depolarization pulse stepping from -60 to $+10 \mathrm{mV}$, was not affected by 1S,3R-ACPD $(200 \mu \mathrm{M})$ either (Fig. $6 B, n=5$ cells, $7.12 \pm 0.62$ and $7.20 \pm 0.57 \mathrm{nA}$ for control and 1S,3R-ACPD, respectively; paired $t$-test $P>0.05$ ). Consistent with the lack of modulation on $I_{\mathrm{Na}^{+}}$and $I_{\mathrm{K}^{+}}, 1 \mathrm{~S}, 3 \mathrm{R}-\mathrm{ACPD}$ did not change the firing properties of $\mathrm{NM}$ neurons in response to current injections including threshold current (the minimal
A

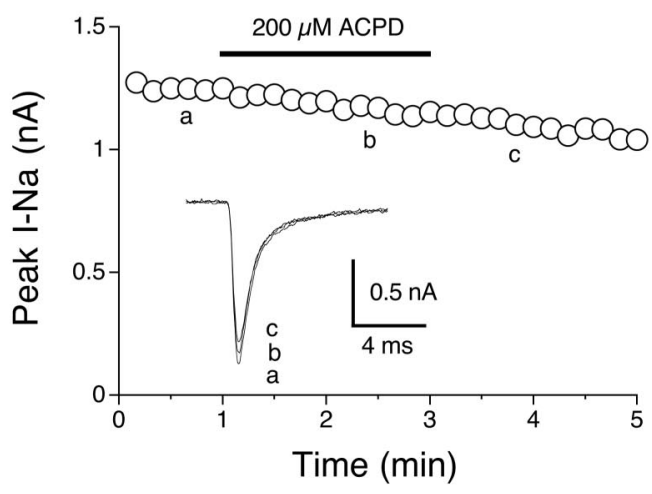

C

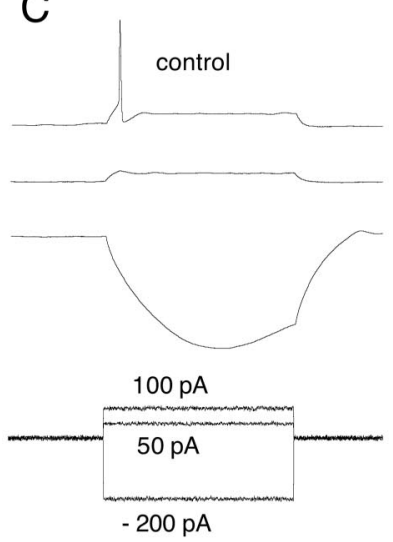

B

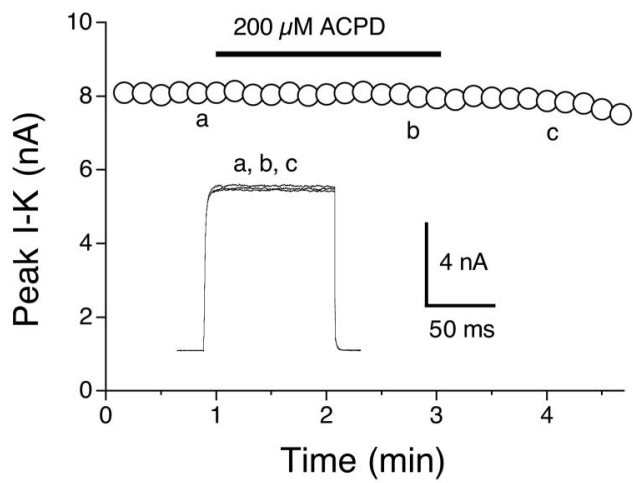

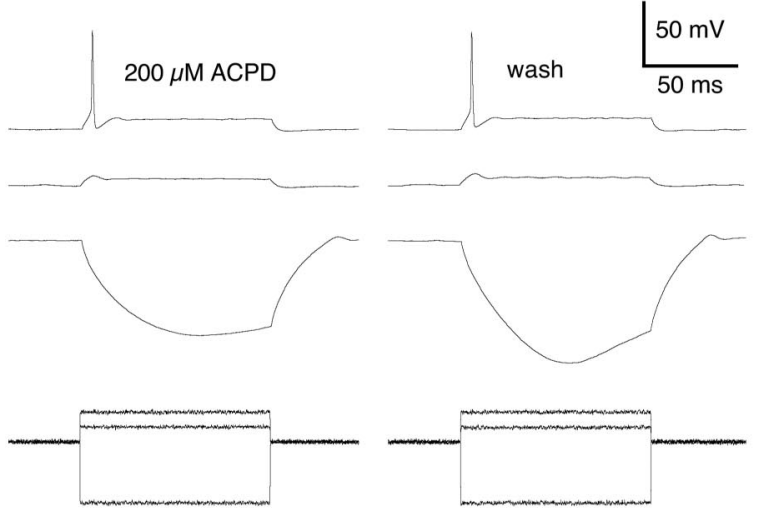

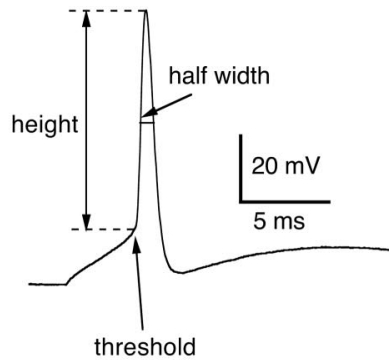

FIG. 6. (1S,3R)-1-aminocyclopentane-1,3-dicarbosylic acid (1S,3R-ACPD) did not modify $I_{\mathrm{Na}^{+}}, I_{\mathrm{K}^{+}}$, or firing properties of NM neurons. $A$ : we recorded $I_{\mathrm{Na}}{ }^{+}$ using a reduced $\mathrm{NaCl}$ concentration $(40 \mathrm{mM})$ in the external solution to achieve sufficient voltage clamp. The cell was held at $-60 \mathrm{mV}$, and a 100 -ms depolarizing voltage pulse to $-30 \mathrm{mV}$ was applied once every $10 \mathrm{~s}$ to acquire $I_{\mathrm{Na}^{+}}$. Application of $1 \mathrm{~S}, 3 \mathrm{R}$-ACPD $(200 \mu \mathrm{M})$ did not change the peak $I_{\mathrm{Na}^{+}}$; the current traces obtained before, during, and after the application showed a small rundown (see the inset). $B$ : NM neurons are well known to have robust outward $\mathrm{K}^{+}$ conductances. When we held the cell at $-60 \mathrm{mV}$ and applied a depolarizing voltage pulse to $+10 \mathrm{mV}$, a large and noninactivating $I_{\mathrm{K}^{+}}$was recorded. The current was not affected by 1S,3R-ACPD $(200 \mu \mathrm{M})$. The 3 traces obtained before, during, and after the application essentially overlapped (see the inset). $C$ : voltage responses to current injection were not changed by 1S,3R-ACPD. The 3 voltage traces chosen from a series recordings (in response to injected currents ranging from -400 to $800 \mathrm{pA}$ in the increment of $50 \mathrm{pA}$ ) represent the hyperpolarizing, subthreshold, and threshold responses. Inset: how we measured several parameters of the action potential (AP threshold, AP height, and AP half-width). 
current needed to elicit an AP), action potential (AP) threshold, AP height (the difference between the AP threshold and the peak), AP half-width (duration at half-amplitude), rectification (ratio of input resistance depolarized to rest over input resistance hyperpolarized to rest), and the peak values of the depolarization voltage sag (Fig. $6 C$ and Table 1). A small but significant depolarization of the resting membrane potential was observed when 1S,3R-ACPD $(200 \mu \mathrm{M})$ was bath-applied (Table 1). Also a small and consistent decrease in the absolute amplitude of the voltage sag was observed in three cells (the 4 th cell did not show a sag). The voltage sag is likely due to activation of hyperpolarization-activated cationic channels $\left(I_{\mathrm{h}}\right)$, which are also found in other auditory nuclei (Bal and Oertel 2000; Banks et al. 1993; Cuttle et al. 2001).

\section{I S C U S S I O N}

We report three main findings: both LVA and HVA $I_{\mathrm{Ba}^{2+}}$ were observed in NM neurons and four pharmacological types of HVA VGCCs were identified, N-type being the most dominant; activation of mGluRs reliably inhibited both $\mathrm{N}$ - and non-N-type channel HVA $I_{\mathrm{Ba}^{2+}}$ in NM neurons and agonists of all three groups of mGluRs produced some inhibition of HVA $I_{\mathrm{Ba}^{2+}}$; and voltage-gated $\mathrm{Na}^{+}$and $\mathrm{K}^{+}$currents and firing properties of NM neurons were not subject to modulation by mGluRs. Therefore activation of mGluRs appears to limit depolarization-induced $\mathrm{Ca}^{2+}$ influx through VGCCs, participating in regulation of $\mathrm{Ca}^{2+}$ homeostasis of NM neurons.

\section{$N$ - not L-type channel HVA $I_{B a^{2+}}$ dominates in NM neurons}

The general characteristics of voltage dependence and kinetics of LVA and HVA $I_{\mathrm{Ba}^{2+}}$ is similar to what was reported by Koyano et al. (1996). However, the relative abundance of $\mathrm{Ca}^{2+}$ channel types we observed differed from their report. Our pharmacological analyses indicated that the N-type channels contributed over $50 \%$ to the total HVA $I_{\mathrm{Ba}^{2+}}$. Koyano et al. (1996), on the other hand, reported predominantly L-type HVA VGCC, based on the fact that nifedipine $(20 \mu \mathrm{M})$, an L-type channel antagonist, almost completely blocked the HVA $I_{\mathrm{Ba}^{2+}}$. Technical difficulties related to reliable recording of $\mathrm{Ca}^{2+}$ currents are probably responsible for the discrepancy. It is well known that $\mathrm{Ca}^{2+}$ channel currents are more susceptible to

TABLE 1. Effects of $1 S, 3 R-A C P D(200 \mu M)$ on firing properties of NM neurons

\begin{tabular}{lcccc}
\hline \hline & \multicolumn{1}{c}{ Control } & ACPD & $\begin{array}{c}\text { Paired } t \text {-Test } \\
P \text { Value }\end{array}$ \\
\hline$n$ & \multicolumn{5}{c}{4} & 4 & \\
RMP, mV & $-56.8 \pm 1.5$ & -55.5 & \pm 1.7 & $<0.05^{*}$ \\
Threshold I, pA & $170 \pm 65$ & 170 & \pm 65 & $>0.05$ \\
AP threshold, mV & $-43.4 \pm 2.5$ & $-43.7 \pm 3.3$ & $>0.05$ \\
AP height, mV & $61.5 \pm 8.9$ & $58.7 \pm 7.9$ & $>0.05$ \\
AP half width, ms & $0.78 \pm 0.05$ & $0.78 \pm 0.07$ & $>0.05$ \\
Rectification & $0.16 \pm 0.05$ & $0.16 \pm 0.04$ & $>0.05$ \\
Sag peak, mV & $-196 \quad \pm 12$ & $-185 \quad \pm 16$ & $>0.05$ \\
\hline
\end{tabular}

Sag peak was measured as the peak value of the voltage hyperpolarization in response to $-0.4 \mathrm{nA}$ current injection (due to the lack of a sag in 1 cell, the measurements for this parameter were done in 3 cells). Means \pm SD are reported. RMP, resting membrane potential; AP, action potential; rectification, ratio of input resistance depolarized to rest over input resistance hyperpolarized to rest. rundown than other ionic channel currents (Byerly and Yazejian 1986; Hao et al. 1999). The nearly complete blockade of HVA $I_{\mathrm{Ba}^{2+}}$ by nifedipine reported by Koyano and colleagues may have resulted from the additive effects of L-channel blockade and rundown of $\mathrm{Ca}^{2+}$ conductances. Using the same internal and external solutions as Koyano et al. (1996), we found that rundown of the HVA $I_{\mathrm{Ba}^{2+}}$ was considerably faster than that recorded using our solutions $(n=8$ cells, data not shown). Under our recording conditions, bath application of another L-type $\mathrm{Ca}^{2+}$ channel blocker (nimodipine, $10 \mu \mathrm{M}$ ) blocked $17.9 \pm 4.2 \%$ (Fig. 2) of the HVA $I_{\mathrm{Ba}^{2+}}$, and bath application of nifedipine $(20 \mu \mathrm{M})$ for 5 min inhibited only $31.8 \pm 4.7 \%$ of the current ( $n=4$ cells, data not shown).

Our finding that $\mathrm{N}$ - not L-type $\mathrm{Ca}^{2+}$ channels dominate in NM neurons also contradicts with an earlier report from our laboratory in which $\mathrm{Ca}^{2+}$ imaging was used to show that $\mathrm{Ca}^{2+}$ transients in response to high concentration of $\mathrm{KCl}$ were largely blocked by L-type channel blocker, nifedipine (Lachica et al. 1995). Although the reason for this discrepancy is unclear, given the difference in inactivation of L-type $(\tau>500$ ms) versus $\mathrm{N}_{-}, \mathrm{P} / \mathrm{Q}-$, and R-type $(\tau \approx 50-80 \mathrm{~ms})$ channels (Hille 2001), the difference between the current study and Lachica et al. (1995) may be due to the difference in the time course of the depolarization used to activate VGCCs. We applied depolarizing voltage pulses with duration of $100 \mathrm{~ms}$ during which little inactivation of the HVA $I_{\mathrm{Ba}^{2+}}$ was seen, while Lachica et al. (1995) used bath application of $\mathrm{KCl}$ to depolarize NM neurons, during which N-, P/Q- and R-type channels may be inactivated at an early time so that the $\mathrm{Ca}^{2+}$ transients are largely due to influx through less inactivating L-type channels and blocking L-type channels largely eliminated the remaining $\mathrm{Ca}^{2+}$ transients.

On the presynaptic terminals from the auditory nerve onto $\mathrm{NM}$ neurons, $\mathrm{N}$-type $\mathrm{Ca}^{2+}$ channels seem to predominate and P/Q-type channels may be present, while L- and R-type channels appear to be absent (Sivaramakrishnan and Laurent 1995). In contrast, somatic P/Q-type channel currents in NM neurons seem to be the smallest components (12\% of the total HVA $I_{\mathrm{Ba}^{2+}}$ ) and both L- and R-type channels appear to be abundant. In bushy cells of anterioventral cochlear nucleus (AVCN), the mammalian homologue of NM, multiple $\mathrm{HVA} \mathrm{Ca}^{2+}$ channels are found as well with about equal proportion $(\sim 30 \%)$ of L-, $\mathrm{N}-$, and R-type channels and minimal P/Q-type channels (Doughty et al. 1998). In our experiments, blocking N-type channels did not result in noticeable changes in parameters of current injection-induced action potentials (AP) of NM neurons, including AP threshold, latency, height, maximal rising slope, or width ( $n=5$ cells, data not shown). This suggests that $\mathrm{N}$-type $\mathrm{Ca}^{2+}$ channel currents don't participate in the generation of APs in NM neurons. N-type channels are also found at the soma of other neuronal types (reviewed in Stefani et al. 1996). Hence, it does not seem that auditory neurons are unique in the somatic expression of $\mathrm{N}$-type $\mathrm{Ca}^{2+}$ channels for their particular functions. The distinct functions of multiple VGCCs in the CNS neurons are not clear except their pharmacological sensitivity (Hille 2001).

\section{Involvement of different mGluRs in the modulation of VGCCs}

There are at least eight mammalian cloned mGluRs divided into three groups according to their sequence similarity, phar- 
macological properties, and signaling pathways (reviewed in Bruno et al. 2001). Inhibition of HVA VGCCs by activation of mGluRs has now been reported in many other neuronal types and the relative involvement of different mGluRs in the modulation of VGCCs appears to vary widely between different neurons (reviewed in Catterall 2000; Stefani et al. 1996).

Results of the current study indicate the involvement of all three groups of mGluRs in modulation of VGCCs of NM neurons, with group III appearing predominant. This is an uncommon situation in which all three groups of mGluRs seem to exist on the postsynaptic neurons and all target to VGCCs. In many other systems, group I and II mGluRs are found to be located on postsynaptic cells, modulating a variety of cellular processes; and Group II and III mGluRs on presynaptic terminals, functioning as either autoreceptors modulating glutamatergic transmission or heteroreceptors modulating nonglutamatergic transmission (Cartmell and Schoepp 2000). However, we remain cautious with respect to the relative abundance of the mGluR groups on NM neurons since results obtained by experiments using mGluR antagonists (MCPG and CPPG) were inconclusive. Genetic and histochemical analyses are needed to determine which group(s) of mGluR RNA are expressed and the sites of protein expression in NM neurons.

\section{Lack of modulation of firing properties of NM neurons by $m$ GluRs}

The amount of depolarization-induced $\mathrm{Ca}^{2+}$ influx through VGCCs is presumably proportional to action potential (AP) parameters such as spike frequency and AP width. These parameters are known to be modulated by mGluRs in some other systems. For example, neuronal excitability, measured by the number of spikes in response to prolonged depolarizing current injection, is enhanced by activation of group I mGluRs in hippocampal CA1 neurons (Ireland and Abraham 2002). Also in CA1 neurons, mGluR agonist 1S,3R-ACPD broadens the width of APs elicited by current injection (Hu and Storm 1991). By increasing neuronal excitability, mGluRs reduce firing adaptation of hippocampal CA1 neurons (Desai et al. 1992; Pacelli and Kelso 1991) or CA3 neurons (Charpak et al. 1990). Modulation of $I_{\mathrm{K}^{+}}$or $I_{\mathrm{Na}^{+}}$by mGluRs is presumably the underlying mechanism for these phenomena (reviewed in Anwyl 1999; Cantrell and Catterall 2001).

We found no modulation of $I_{\mathrm{K}^{+}}$or $I_{\mathrm{Na}^{+}}$of NM neurons by stimulation of mGluRs, consistent with the observation that the firing properties (threshold current, AP threshold, AP height, AP half-width, and rectification) of NM neurons are not altered by activation of mGluRs. However, depolarization of the resting membrane potential (RMP) might be partially correlated with the activation of $I_{\mathrm{h}}$ channels (shown as a reduction in the absolute amplitude of the voltage sag in Fig. 6). $I_{\mathrm{h}}$ channels can influence RMP (Bal and Oertel 2000; Maccaferri et al. 1993) and are enhanced by increased levels of cAMP (Banks et al. 1993; Cuttle et al. 2001). Therefore activation of mGluRs by $1 \mathrm{~S}, 3 \mathrm{R}-\mathrm{ACPD}$ in NM neurons may increase cAMP level (Lachica et al. 1995) and then activate $I_{\mathrm{h}}$ channels, resulting in membrane depolarization. Although 1S,3R-ACPD caused a depolarization of the RMP, it is unlikely that $\mathrm{Ca}^{2+}$ flux through HVA VGCCs in NM neurons will be influenced because the change in RMP is very small $(1.3 \mathrm{mV})$ and the changed RMP is below the HVA VGCC activation potential
(Fig. 1) so that the inactivation of the channels, if any, would be little. Therefore inhibition of HVA VGCCs by activation of mGluRs in NM neurons could induce a net reduction of $\mathrm{Ca}^{2+}$ influx.

\section{Functional significance}

Intracellular signaling cascades activated by mGluRs result in a large number of important modulatory functions (reviewed in Anwyl 1999; Cartmell and Schoepp 2000; De Blasi et al. 2001). Protection of neurons from damage due to excitotoxicity has been previously reported (reviewed in Bruno et al. 2001) and the protective effect can be dependent on inhibition of $\mathrm{Ca}^{2+}$ influx through VGCCs (Colwell and Levine 1999; Kimura et al. 1999). These studies highlight the fact that because of the nature of their coding functions and their synaptic input, neurons face a variety of challenges with respect to $\mathrm{Ca}^{2+}$ homeostasis and $\mathrm{Ca}^{2+}$ signaling. This has been emphasized with respect to motoneurons by Keller and associates (Lips and Keller 1999; Vanselow and Keller 2000).

NM neurons and their mammalian homologs in the anteroventral cochlear nucleus (AVCN) fire spontaneously at very high rates $(\leq 100 \mathrm{~Hz})$ and are driven at rates upward of $250 \mathrm{~Hz}$ (Born et al. 1991; Koppl 1997; Rubel and Parks 1975; Rubsamen et al. 1995; Stopp and Whitfield 1961; Sullivan and Konishi 1984; Warchol and Dallos 1990). These chronically high activity levels in combination with the constraints of using the $\mathrm{Ca}^{2+}$ permeable AMPA receptor (Parks 2000), places an unusually high demand on cochlear nucleus neurons with respect to $\mathrm{Ca}^{2+}$ homeostasis. In several previous reports, we have stressed that activation of mGluRs is one of the strategies to maintain $\mathrm{Ca}^{2+}$ homeostasis in NM neurons (Rubel and Fritzsch 2002; Rubel et al. 2004). The global inhibitory effect on $\mathrm{Ca}^{2+}$ conductance by mGluR activation, shown in the current study, may limit depolarization-induced $\mathrm{Ca}^{2+}$ entry into NM neurons, participating in regulation of $\mathrm{Ca}^{2+}$ homeostasis of these neurons. On the other hand, it is important to note that this mechanism inhibited $\sim 20 \%$ of $\mathrm{HVA} \mathrm{I}_{\mathrm{Ba}^{2+}}$ under the conditions of our study, and this mechanism presumably works in concert with a host of other processes that appear hypertrophied in these neurons and their mammalian counterparts. For example, previous studies from our laboratory suggest that $\mathrm{Ca}^{2+}$ release from intracellular stores is modulated by mGluRs (Kato and Rubel 1999; Kato et al. 1996). In addition, NM neurons and AVCN neurons express unusually high levels of the major $\mathrm{Ca}^{2+}$ binding proteins, calbindin, calretinin, and parvalbumin (Braun 1990; Caicedo et al. 1996; Korada and Schwartz 2000; Kubke et al. 1999; Parks et al. 1997; Vater and Braun 1994). It will be of considerable interest to determine the differential contributions of these and other $\mathrm{Ca}^{2+}$ regulating mechanisms to insuring survival of both young and adult neurons.

\section{A C K N O W LE D G MENTS}

We thank H. Brew, I. D. Forsythe, J. X Gittelman, and D. J. Perkel for helpful comments on earlier versions of this manuscript and L. Johnson for manuscript-preparation assistance.

\section{G R A N T S}

This work was supported by National Institute of Deafness and Other Communication Disorder Grants DC-03829, DC-00018, and DC-04661. 


\section{REFERENCES}

Anwyl R. Metabotropic glutamate receptors: electrophysiological properties and role in plasticity. Brain Res Brain Res Rev 29: 83-120, 1999.

Aosaki T and Kasai H. Characterization of two kinds of high-voltageactivated Ca-channel currents in chick sensory neurons. Differential sensitivity to dihydropyridines and omega-conotoxin GVIA. Pfluegers 414: 150-156, 1989.

Aronica E, Dell'Albani P, Condorelli DF, Nicoletti F, Hack N, and Balazs R. Mechanisms underlying developmental changes in the expression of metabotropic glutamate receptors in cultured cerebellar granule cells: homologous desensitization and interactive effects involving $N$-methyl-Daspartate receptors. Mol Pharmacol 44: 981-989, 1993.

Bal R and Oertel D. Hyperpolarization-activated, mixed-cation current $\left(I_{\mathrm{h}}\right)$ in octopus cells of the mammalian cochlear nucleus. J Neurophysiol 84: 806-817, 2000.

Banks MI, Pearce RA, and Smith PH. Hyperpolarization-activated cation current $\left(I_{\mathrm{h}}\right)$ in neurons of the medial nucleus of the trapezoid body: voltage-clamp analysis and enhancement by norepinephrine and cAMP suggest a modulatory mechanism in the auditory brain stem. $J$ Neurophysiol 70: 1420-1432, 1993.

Barnes-Davies M, and Forsythe ID. Pre- and postsynaptic glutamate receptors at a giant excitatory synapse in rat auditory brainstem slices. J Physiol 488: 387-406, 1995.

Bean BP. Neurotransmitter inhibition of neuronal calcium currents by changes in channel voltage dependence. Nature 340: 153-156, 1989.

Boland LM, Morrill JA, and Bean BP. Omega-conotoxin block of N-type calcium channels in frog and rat sympathetic neurons. J Neurosci 14: 5011-5027, 1994.

Born DE, Durham D, and Rubel EW. Afferent influences on brain stem auditory nuclei of the chick: nucleus magnocellularis neuronal activity following cochlea removal. Brain Res 557: 37-47, 1991.

Braun K. Calcium-binding proteins in avian and mammalian central nervous system: localization, development and possible functions. Prog Histochem Cytochem 21: 1-64, 1990.

Bruno V, Battaglia G, Copani A, D'Onofrio M, Di Iorio P, De Blasi A, Melchiorri D, Flor PJ, and Nicoletti F. Metabotropic glutamate receptor subtypes as targets for neuroprotective drugs. J Cereb Blood Flow Metab 21: 1013-1033, 2001.

Byerly $\mathbf{L}$ and Yazejian B. Intracellular factors for the maintenance of calcium currents in perfused neurones from the snail, Lymnaea stagnalis. J Physiol 370: 631-650, 1986.

Caicedo A, d'Aldin C, Puel JL, and Eybalin M. Distribution of calciumbinding protein immunoreactivities in the guinea pig auditory brain stem. Anat Embryol 194: 465-487, 1996.

Cantrell AR and Catterall WA. Neuromodulation of $\mathrm{Na}^{+}$channels: an unexpected form of cellular plasticity. Nat Rev Neurosci 2: 397-407, 2001.

Cartmell J and Schoepp DD. Regulation of neurotransmitter release by metabotropic glutamate receptors. J Neurochem 75: 889-907, 2000.

Catania MV, Aronica E, Sortino MA, Canonico PL, and Nicoletti F. Desensitization of metabotropic glutamate receptors in neuronal cultures. J Neurochem 56: 1329-1335, 1991.

Catterall WA. Structure and regulation of voltage-gated $\mathrm{Ca}^{2+}$ channels. Annu Rev Cell Dev Biol 16: 521-555, 2000.

Charpak S, Gahwiler BH, Do KQ, and Knopfel T. Potassium conductances in hippocampal neurons blocked by excitatory amino-acid transmitters. Nature 347: 765-767, 1990.

Choi S and Lovinger DM. Metabotropic glutamate receptor modulation of voltage-gated $\mathrm{Ca}^{2+}$ channels involves multiple receptor subtypes in cortical neurons. J Neurosci 16: 36-45, 1996.

Colwell CS and Levine MS. Metabotropic glutamate receptor modulation of excitotoxicity in the neostriatum: role of calcium channels. Brain Res 833: 234-241, 1999.

Conn PJ and Pin JP. Pharmacology and functions of metabotropic glutamate receptors. Апnи Rev Pharmacol Toxicol 37: 205-237, 1997.

Cuttle MF, Rusznak Z, Wong AY, Owens S, and Forsythe ID. Modulation of a presynaptic hyperpolarization-activated cationic current $\left(I_{\mathrm{h}}\right)$ at an excitatory synaptic terminal in the rat auditory brain stem. $J$ Physiol 534: 733-744, 2001.

De Blasi A, Conn PJ, Pin J, and Nicoletti F. Molecular determinants of metabotropic glutamate receptor signaling. Trends Pharmacol Sci 22: $114-$ 120,2001

Desai MA, Smith TS, and Conn PJ. Multiple metabotropic glutamate receptors regulate hippocampal function. Synapse 12: 206-213, 1992.
Doughty JM, Barnes-Davies M, Rusznak Z, Harasztosi C, and Forsythe ID. Contrasting $\mathrm{Ca}^{2+}$ channel subtypes at cell bodies and synaptic terminals of rat anterioventral cochlear bushy neurons. J Physiol 512: 365-376, 1998.

Garcia-Ferreiro RE, Hernandez-Ochoa EO, and Garcia DE. Modulation of $\mathrm{N}$-type $\mathrm{Ca}^{2+}$ channel current kinetics by PMA in rat sympathetic neurons. Pfluegers 442: 848-858, 2001.

Hao LY, Kameyama A, and Kameyama M. A cytoplasmic factor, calpastatin and ATP together reverse run-down of $\mathrm{Ca}^{2+}$ channel activity in guineapig heart. J Physiol 514: 687-699, 1999.

Hayashi Y, Sekiyama N, Nakanishi S, Jane DE, Sunter DC, Birse EF, Udvarhelyi PM, and Watkins JC. Analysis of agonist and antagonist activities of phenylglycine derivatives for different cloned metabotropic glutamate receptor subtypes. J Neurosci 14: 3370-3377, 1994.

Hille B. Ion Channels of Excitable Membranes (3rd ed.). Sunderland, MA: Sinauer, 2001.

Hu GY and Storm JF. Excitatory amino acids acting on metabotropic glutamate receptors broaden the action potential in hippocampal neurons. Brain Res 568: 339-344, 1991.

Ireland DR and Abraham WC. Group I mGluRs increase excitability of hippocampal CA1 pyramidal neurons by a PLC-independent mechanism. J Neurophysiol 88: 107-116, 2002.

Kammermeier PJ and Ikeda SR. Desensitization of group I metabotropic glutamate receptors in rat sympathetic neurons. J Neurophysiol 87: $1669-$ 1676, 2002.

Kato BM, Lachica EA, and Rubel EW. Glutamate modulates intracellular $\mathrm{Ca}^{2+}$ stores in brain stem auditory neurons. J Neurophysiol 76: 646-650, 1996.

Kato BM and Rubel EW. Glutamate regulates $\mathrm{IP}_{3}$-type and CICR stores in the avian cochlear nucleus. J Neurophysiol 81: 1587-1596, 1999.

Kimura M, Katayama K, and Nishizawa Y. Role of glutamate receptors and voltage-dependent calcium channels in glutamate toxicity in energy-compromised cortical neurons. Jpn J Pharmacol 80: 351-358, 1999.

Koppl C. Frequency tuning and spontaneous activity in the auditory nerve and cochlear nucleus magnocellularis of the barn owl Tyto alba. J Neurophysiol 77: 364-377, 1997.

Korada S and Schwartz IR. Calcium binding proteins and the AMPA glutamate receptor subunits in gerbil cochlear nucleus. Hear Res 140: 23-37, 2000.

Koyano K, Funabiki K, and Ohmori H. Voltage-gated ionic currents and their roles in timing coding in auditory neurons of the nucleus magnocellularis of the chick. Neurosci Res 26: 29-45, 1996.

Kubke MF, Gauger B, Basu L, Wagner H, and Carr CE. Development of calretinin immunoreactivity in the brainstem auditory nuclei of the barn owl (Tyto alba). J Comp Neurol 415: 189-203, 1999.

Lachica EA, Rubsamen R, Zirpel L, and Rubel EW. Glutamatergic inhibition of voltage-operated calcium channels in the avian cochlear nucleus. J Neurosci 15: 1724-1734, 1995.

Lambert NA and Wilson WA. High-threshold $\mathrm{Ca}^{2+}$ currents in rat hippocampal interneurons and their selective inhibition by activation of GABA(B) receptors. J Physiol 492: 115-127, 1996.

Lips MB and Keller BU. Activity-related calcium dynamics in motoneurons of the nucleus hypoglossus from mouse. J Neurophysiol 82: 2936-2946, 1999.

Lu Y and Rubel EW. Activation of metabotropic glutamate receptors inhibits voltage-gated calcium channel currents of chicken nucleus magnocellularis neurons. Fourth International mGluR Meeting Abstract, Taormina, SicilyItaly, 2002.

Maccaferri G, Mangoni M, Lazzari A, and DiFrancesco D. Properties of the hyperpolarization-activated current in rat hippocampal CA1 pyramidal cells. J Neurophysiol 69: 2129-2136, 1993.

McCarthy RT and TanPiengco PE. Multiple types of high-threshold calcium channels in rabbit sensory neurons: high-affinity block of neuronal L-type by nimodipine. J Neurosci 12: 2225-2234, 1992.

Pacelli GJ and Kelso SR. Trans-ACPD reduces multiple components of synaptic transmission in the rat hippocampus. Neurosci Lett 132: 267-269, 1991.

Parks TN. The AMPA receptors of auditory neurons. Hear Res 147: 77-91, 2000.

Parks TN, Code RA, Taylor DA, Solum DA, Strauss KI, Jacobowitz DM, and Winsky L. Calretinin expression in the chick brain stem auditory nuclei develops and is maintained independently of cochlear nerve input. J Comp Neurol 383: 112-121, 1997.

Randall A and Tsien RW. Pharmacological dissection of multiple types of $\mathrm{Ca}^{2+}$ channel currents in rat cerebellar granule neurons. J Neurosci 15 : 2995-3012, 1995. 
Regan LJ. Voltage-dependent calcium currents in Purkinje cells from rat cerebellar vermis. J Neurosci 11: 2259-2269, 1991.

Rubel EW and Fritzsch B. Auditory system development: primary auditory neurons and their targets. Annu Rev Neurosci 25: 51-101, 2002.

Rubel EW and Parks TN. Organization and development of brain stem auditory nuclei of the chicken: tonotopic organization of $\mathrm{n}$. magnocellularis and n. laminaris. J Comp Neurol 164: 411-433, 1975.

Rubel EW, Parks TN, and Zirpel L. Assembling, connecting and maintaining the cochlear nucleus. In: Plasticity of the Auditory System, edited by Parks TN, Rubel EW, Fay RR, and Popper AN. 2004, chap. 2, p. 8-48.

Rubsamen R, Mills DM, and Rubel EW. Effects of furosemide on distortion product otoacoustic emissions and on neuronal responses in the anteroventral cochlear nucleus. J Neurophysiol 74: 1628-1638, 1995.

Sahara Y and Westbrook GL. Modulation of calcium currents by a metabotropic glutamate receptor involves fast and slow kinetic components in cultured hippocampal neurons. J Neurosci 13: 3041-3050, 1993.

Sayer RJ. Group I metabotropic glutamate receptors mediate slow inhibition of calcium current in neocortical neurons. J Neurophysiol 80: 1981-1988, 1998.

Sivaramakrishnan $\mathbf{S}$ and Laurent G. Pharmacological characterization of presynaptic calcium currents underlying glutamatergic transmission in the avian auditory brain stem. $J$ Neurosci 15: 6576-6585, 1995.

Stefani A, Pisani A, Mercuri NB, and Calabresi P. The modulation of calcium currents by the activation of mGluRs. Functional implications. Mol Neurobiol 13: 81-95, 1996.

Stopp PE and Whitfield IC. Unit responses from brain-stem nuclei in the pigeon. J Physiol 158: 165-177, 1961.

Sullivan WE and Konishi M. Segregation of stimulus phase and intensity coding in the cochlear nucleus of the barn owl. J Neurosci 4: 1787-1799, 1984.
Swartz KJ, Bean BP. Inhibition of calcium channels in rat CA3 pyramidal neurons by a metabotropic glutamate receptor. J Neurosci 12: 4358-4371, 1992.

Vanselow BK and Keller BU. Calcium dynamics and buffering in oculomotor neurones from mouse that are particularly resistant during amyotrophic lateral sclerosis (ALS)-related motoneurone disease. J Physiol 525: 433445, 2000.

Vater M and Braun K. Parvalbumin, calbindin D-28k, and calretinin immunoreactivity in the ascending auditory pathway of horseshoe bats. J Comp Neurol 341: 534-558, 1994.

Warchol ME and Dallos P. Neural coding in the chick cochlear nucleus. J Comp Physiol [A] 166: 721-734, 1990.

Yu SP, Canzoniero LM, and Choi DW. Ion homeostasis and apoptosis. Curr Opin Cell Biol 13: 405-411, 2001.

Zheng W, Rampe D, and Triggle DJ. Pharmacological, radioligand binding, and electrophysiological characteristics of FPL 64176, a novel nondihydropyridine $\mathrm{Ca}^{2+}$ channel activator, in cardiac and vascular preparations. Mol Pharmacol 40: 734-741, 1991.

Zirpel L, Janowiak MA, Veltri CA, and Parks TN. AMPA receptormediated, calcium-dependent CREB phosphorylation in a subpopulation of auditory neurons surviving activity deprivation. J Neurosci 20: 6267-6275, 2000.

Zirpel L, Lachica EA, and Lippe WR. Deafferentation increases the intracellular calcium of cochlear nucleus neurons in the embryonic chick. J Neurophysiol 74: 1355-1357, 1995.

Zirpel L, Lippe WR, and Rubel EW. Activity-dependent regulation of $\left[\mathrm{Ca}^{2+}\right]_{\mathrm{i}}$ in avian cochlear nucleus neurons: roles of protein kinase A and $\mathrm{C}$ and relation to cell death. J Neurophysiol 79: 2288-2302, 1998.

Zirpel L and Rubel EW. Eighth nerve activity regulates intracellular calcium concentration of avian cochlear nucleus neurons via a metabotropic glutamate receptor. J Neurophysiol 76: 4127-4139, 1996. 